\title{
PENDAMPINGAN PENGEMBANGAN USAHA INDUSTRI TAHU DI DESA NOWA KECAMATAN WOJA KABUPATEN DOMPU
}

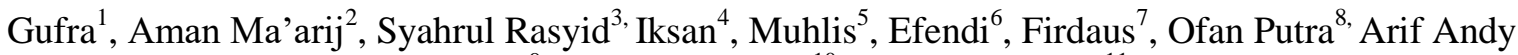 \\ Maulana ${ }^{9}$, Ade Ermin Putri ${ }^{10}$, dan Adi Samran ${ }^{11}$
}

${ }^{1}$ Sekolah Tinggi Ilmu Hukum Muhammadiyah Bima, Kota Bima-Indonesia

${ }^{2}$ Sekolah Tinggi Ilmu Hukum Muhammadiyah Bima Kota Bima-Indonesia

${ }^{3}$ Sekolah Tinggi Ilmu Hukum Muhammadiyah Bima, Kota Bima-Indonesia

${ }^{4}$ Sekolah Tinggi Ilmu Hukum Muhammadiyah Bima, Kota Bima-Indonesia

${ }^{5}$ Sekolah Tinggi Ilmu Hukum Muhammadiyah Bima, Kota Bima-Indonesia

${ }^{6}$ Sekolah Tinggi Ilmu Hukum Muhammadiyah Bima, Kota Bima-Indonesia

${ }^{7}$ Sekolah Tinggi Ilmu Hukum Muhammadiyah Bima, Kota Bima-Indonesia

${ }^{8}$ Sekolah Tinggi Ilmu Hukum Muhammadiyah Bima, Kota Bima-Indonesia

${ }^{9}$ Sekolah Tinggi Ilmu Hukum Muhammadiyah Bima, Kota Bima-Indonesia

${ }^{10}$ Sekolah Tinggi Ilmu Hukum Muhammadiyah Bima, Kota Bima-Indonesia

${ }^{11}$ Sekolah Tinggi Ilmu Hukum Muhammadiyah Bima, Kota Bima-Indonesia

\section{Email : Email: azisgufran@gmail.com}

\begin{abstract}
ABSTRAK
\section{PENDAHULUAN}

Di era otonomi daerah saat ini pemerintah daerah menjadi sangat berkepentingan untuk mampu menciptakan kondisi untuk memobilisasi sumber daya, kapasitas dan ketrampilan yang terdapat dan dimiliki oleh lokal (daerah) untuk dimanfaatkan bagi tercapainya pembangunan ekonomi daerah yang berkualitas dan berkelanjutan. Salah satu
\end{abstract}

Strategi pengembangan usaha produksi tahu pada perusahaan Pabrik Tahu di Desa Nowa, Kec Woja, Kab Dompu NTB. Jenis penelitian ini merupakan kualitatif deskriptif dengan pengumpulan data menggunakan wawancara. Pabrik Tahu Saudara merupakan perusahaan keluarga dengan bidang usaha mengolah kacang kedelai menjadi tahu. Pabrik Tahu Saudara memiliki 4 fungsi bisnis, yaitu marketing, accounting/finance, production/operation, dan sumber daya manusia. Hasil penelitian menunjukkan bahwa permintaan pasar akan produk tahu melebihi kapasitas yang dapat disediakan perusahaan, pasar potensial masih sangat besar sebagai peluang perusahaan, namun industri ini menghadapi tantangan berupa ketidakstabilan bahan bahan baku sehingga seharusnya perusahaan meningkatkan kapasitas untuk dapat memenuhi permintaan pasar dengan strategi cost leadership, differentiation, dan backward integration.

Kata Kunci: Pengembangan Usaha; Tahu; Nowa; Dompu.

sumber daya ekonomi adalah usaha mikro, kecil dan menengah di kabupaten/kota yang memiliki arti dan peran sangat penting bagi perekonomian di Indonesia.

Di kabupaten Dompu, tingkat konsumsi masyarakat dan sekitarnya dalam mengkonsumsi makanan olahan tahu di pasaran siap saji dengan penyajian yang bervariasi menjadikan tumbuh dan berkembangnya sentra industri tahu di Desa 
Nowa. Industri tahu merupakan salah satu mata pencaharian khas bagi sebagian masyarakat, dan menjadi salah satu industri yang berbasis sumber daya ekonomi bagi masyarakat Desa. Berdasar informasi yang di himpun melalui wawancara lapangan, industri kecil tahu di Desa Nowa dianggap sudah cukup berkembang dan dapat menjadi peluang kerja untuk masyarakat dalam mengembangkan keterampilan usaha.

Sudah menjadi suatu kewajiban manusia untuk bertahan hidup dan mengembangkan bakat dan keterampilan usaha ditengah kehidupan yang bermasyarakat. Untuk bertahan hidup, manusia perlu berinteraksi dengan sesama manusia lain, terutama dalam menjalin hubungan kerjasama yang saling menguntungkan, hal itu juga menjadi faktor penyadaran utama bagi masyarakat Desa Nowa untuk lebih terampi dalam meningkatkan ekonomi rumah tangga melalui hubungan perdagangan dan sistem pemasaran.

Dengan banyaknya jumlah penduduk, peluang untuk mendapatkan pekerjaan jadi semakin kecil. Untuk itu, ada baiknya setiap manusia harus mampu berdiri sendiri dengan usahanya dalam bertahan hidup. Usaha dalam bertahan hidup itu diantaranya dengan membuka sendiri lahan usaha baru untuk di tekuni, baik dalam bentuk usaha kelompok maupun perseorangan. Dengan mempertimbangkan segala sesuatunya, termasuk ketersediaan sarana dan prasarana yang menunjang, yang tidak hanya diciptakan oleh pelaku usaha, tetapi untuk mempermudah juga dilihat dari aspek lingkungan. Oleh karena itu, mendirikan usaha produksi dan perdagangan tahu (PKM) Industri yang di mulai sejak tahun 2011 sampai sekarang masih berkembang, adalah satu cara innovatif masyarakat dalam mengembangkan ekonomi rumah tangga yang menunjang kebutuhan hidup yang tentu membutuhkan biaya dalam setiap hari nya, agar tetap bertahan di lingkungan masyarakat, dan mampu membukakan lapangan pekerjaan untuk mengurangi angka pengangguran di Desa Nowa.

Berdasarkan gambaran umum atas kondisi tata letak pembagian wilayah kecamatan di Kabupaten Dompu. Woja adalah sebuah kecamatan di Kabupaten Dompu, Nusa Tenggara Barat, Indonesia. Kecamatan ini berjarak 5 kilometer dari ibu kota kabupaten Dompu ke arah barat, dan terdaftar sebagai wilayah kecamatan dengan 
jumlah populasi terbanyak yang membawahi 14 wilayah otonom Desa.

Dalam data penataan wilayah, dengan adanya pasar sentral yang menjadi pusat perdagangan masyarakat (sandang, papan, dan pangan), kondisi inilah yang membentuk karakter kewirausahaan masyarakat dari berbagai aspek perdagangan, khususnya masyarakat Desa Nowa yang hidup ditengah pasar sentral daerah dengan kelompok usaha masyarakat terbanyak, salah satunya adalah pelaku usaha perindustrian tahu "UD. BISA MAJU" milik bapak A dengan terampil membaca peluang ekonomi dengan mengolah biji kedelai menjadi tahu siap jual untuk meningkatkan pendapatan rumah tangga. Tujuan dari usaha ini adalah untuk memasarkan produk olahan tahu hasil produksi masyarakat dengan harga yang terjangkau, memenuhi kebutuhan ekonomi serta tujuan lainnya, lebih khusus bagi mereka yang mencari laba atau untung melalui usaha tahu yang dilakukan dengan pengeceran di pasar. Disamping itu, lebih jauh lagi, masyarakat dapat membuka lapangan kerja sendiri dengan mengolah varian penyajian tahu, yang menjadikan tahu olahan industri sebagai bahan dasar pembuatan tahu krispy. Selain itu, juga dapat menyediakan lapangan kerja untuk orang lain yang di ukur dengan asas manfaat yang meliputi:

1. Adanya manfaat ekonomis untuk masyarakat setempat

2. Adanya kebutuhan masyarakat terhadap barang atau jasa

3. Adanya dukungan dari masyarakat sekitar

4. Adanya peningkatan sosial budaya setempat

5. Adanya bahan baku dan tenaga kerja

6. Adanya sarana dan prasarana

7. Tersedianya lapangan pekerjaan

8. Terjalin hubungan perdagangan antar masyarakat.

\section{METODE}

Jenis penelitian ini merupakan penelitian kualitatif deskriptif. Penelitian kualitatif adalah penelitian yang bersifat alamiah, penelitian yang tidak menggunakan model-model matematik, statistik atau komputer. Penelitian deskriptif membuat deskripsi, gambaran atau lukisan secara sistematis, faktual dan akurat mengenai fakta-fakta, sifat-sifat serta hubungan antarfenomena yang diselidiki. Jenis data dalam penelitian ini adalah data kualitatif. Data kualitatif adalah data yang berasal dari penelitian yang bersifat alamiah, penelitian yang tidak menggunakan model-model matematik, statistik atau komputer. Data kualitatif yang digunakan 
dalam penelitian ini berasal dari informasi usaha dan manajemen pada UD.Pabrik Tahu bapak Amin. Sumber data dalam penelitian ini menggunakan data primer. Data primer adalah data yang diperoleh dengan survey lapangan yang menggunakan semua metode pengumpulan data original. Data primer dalam penelitian ini berupa hasil jawaban wawancara dengan informan tentang profil perusahaan, keadaan lingkungan internal dan eksternal perusahaan. Untuk menentukan sumber informan dalam penelitian ini menggunakan teknik sampling non-probability.

Nonprobability sampling adalah teknik pengambilan sampel yang tidak memberi peluang atau kesempatan yang sama bagi setiap unsur atau anggota populasi untuk dipilih menjadi sampel. Jenis sampling non-probability yang digunakan adalah purposive sampling, yang merupakan teknik pengambilan sampel dimana orang yang akan diwawancarai dipilih dengan pertimbangan dan tujuan tertentu. Sumber informan utama dalam penelitian ini adalah pemilik dari UD. Pabrik Tahu, bapak Amin. Penulis memilih pemilik sebagai sumber informan karena pemilik mengetahui dan mengelola semua hal yang berkaitan dengan pabrik. Anak pemilik UD.Pabrik Tahu Pak Amin juga diwawancarai oleh penulis, karena bagi perusahaan keluarga suksesi ke generasi berikutnya dianggap penting, sehingga perlu melihat dari perspektif penerus usaha keluarga. Di samping itu, anak pemilik UD.Pabrik Tahu
Pak Amin juga telah mulai ikut mengelola perusahaan keluarga ini. Penulis juga memilih mewawancarai pekerja yang sudah lama bekerja di UD. Pabrik Tahu Pak Amin sehingga sudah mengerti secara mendalam tentang Pabrik. Selain itu, penulis juga akan mewawancarai konsumen dari UD.

Pabrik Tahu pak Amin yang telah cukup lama menjadi pelanggan sebagai pihak eksternal perusahaan. Dalam melakukan penelitian ini, peneliti akan mengumpulkan data dengan melakukan wawancara. Jenis wawancara yang dilakukan adalah wawancara semi terstruktur, dimana wawancara tersebut termasuk dalam kategori in-depth interview. Tujuan dari wawancara jenis semi terstruktur adalah untuk menemukan permasalahan secara lebih terbuka, dimana AGORA Vol. 1, No. 2, (2013) pihak yang diajak wawancara diminta pendapat serta ideidenya. Dalam melakukan wawancara, peneliti perlu mendengarkan secara teliti dan mencatat apa yang dikemukakan oleh informan (Sugiyono, 2009, p.233). Penelitian ini menggunakan teknik analisa data perbandingan tetap. Peneliti menggunakan teknik analisa perbandingan tetap karena aktivitas dalam teknik tersebut dapat membantu mempercepat proses dan memperjelas data penelitian. Aktivitas dalam analisis data ada tiga, yaitu reduksi data (data reduction), penyajian data (data display), dan penarikan kesimpulan dan verifikasi (conclusion drawing and verification). Penelitian ini diuji menggunakan metode triangulasi 
sumber. Triangulasi sumber digunakan untuk menguji kredibilitas data dilakukan dengan cara mengecek data yang telah diperoleh melalui beberapa sumber, kemudian data yang didapat tersebut dideskripsikan, dikategorisasikan dan dianalisis sehingga menghasilkan suatu kesimpulan.

\section{HASIL DAN PEMBAHASAN}

Manajemen usaha yang dilakukan Keterangan Produk, Produk yang akan di produksi yaitu Tahu dengan bentuk lebih besar, maka masyarakat luas akan tertarik dan penasaran serta puas dengan produk kami. Harga Produk, Harga yang kami tawarkan cukup terjangkau oleh masyarakat luas. Harga tersebut tergantung dari ukuran produk, semakin besar ukuran produk maka semakin tinggi pula harga yang kami tawarkan. Jalur Penjulan Penjualan Produk dan jasa akan kami lakukan secara indoor dan outdoor, dimana tidak hanya di tempat usaha tapi kami akan keliling daerah sekitarnaya.

Manajemen Penetapan Harga, Harga yang akan dikenakan adalah harga yang diperkirakan akan terjangkau oleh masyarakat sekitar. Adapun permasalahannya adalah apabila harga bahan baku maupun bahan pelengkap lainnya yang kami akan olah menjadi TAHU menjulang tinggi serta adanya beberapa beban yang harus kami perhitungkan, maka produk tersebut akan tidak terlalu laku di pasaran karena beralih ke produk Tahu lain yang lebih murah.
Namun, kami selaku wirausahawan yang handal, maka kami tidak akan berhenti mencoba mencari solusi dari permasalahan tersebut.

Penetapan Haga Produk:

\begin{tabular}{|c|c|c|}
\hline NO. & Harga & Barang \\
\hline 1. & Rp. 1000 & 1 Buah Tahu \\
\hline 2. & Rp. 5000 & 5 Buah Tahu \\
\hline 3. & Rp. 50.000 & 50 Buah Tahu \\
\hline 4. & Rp. 150.000 & 125 Buah Tahu \\
\hline 5. & Rp. 250.000 & 250 Buah Tahu \\
\hline
\end{tabular}

Keuntungan dan kerugian, Apabila usaha ini dilakukan dengan lancar dan sukses, maka secara otomatis kami akan mendapatkan beberapa keuntungan yang cukup besar. Kami berusaha agar usaha kami ini tidak mengalami kerugian. Dengan melakukan manajemen keuangan yang baik. dan Arus Kas, Adapun perhitungan rugi/laba selama proses produksi hingga proses pemasaran TAHU ini dan laba yang diperoleh dalam 1 hari :

1. Modal :

1 Kg kedelai Rp. 12000 x 30 kg / hari = Rp. 360.000

Biaya pembungkus $=$ Rp. 15.000

Biaya transportasi $=$ Rp. 15.000

Total $=$ Rp. 390.000,

2. Hasil produksi

$30 \mathrm{~kg}$ kedelai menghasilkan $=15$ papan tahu 1 papan tahu

$=110$ biji tahu

Total tahu yang di produksi $=15$ papan tahu X 110 biji tahu

Ekonomi, Sosial, dan Budaya | 1366 


$$
=1.650 \text { biji tahu }
$$

3. Harga jual Tahu ini :

1 biji TAHU harganya Rp. 1000 Maka

dalam sehari Rp. $1000 \times 1.650=\mathrm{Rp}$.

1.650 .000

Jadi labanya = Harga Jual - Modal

Rp. $1.650 .000-$ Rp. $390.000=$

Rp.1.260.000

Dengan demikian dapat ditarik kesimpulan sebagai berikut :

1. Modal

Modal 1 kali memproduksi / hari

Rp. 390.000

Modal dalam 1 minggu Rp. 2.730.000

Modal dalam 1 bulan Rp. 11.000.000

2. Laba

Laba dalam 1 hari Rp. 1.260.000

Laba dalam 1 minggu Rp. 8.820.000

Laba dalam 1 bulan Rp. 37.000.000

Usaha pembuatan tahu merupakan salah satu industri pengolahan yang mempunyai prospek yang cerah. Kedelai yang dijadikan sebagai bahan baku dalam pembuatan tahu adalah kedelai berkualitas yang memiliki nilai gizi yang tinggi. Produk yang diolah dilakukan dengan penanganan yang baik disertai dengan syarat-syarat teknisi sanitasi dan higienis sesuai dengan standar mutu yang diinginkan. Pada jaman dulu tahu ini dianggap sebagai makanan masyarakat golongan bawah, namun saat ini tahu telah diterima oleh masyarakat golongan ekonomi menengah ke atas. Hal ini dikarenanakan tahu merupakan bahan makanan yang memiliki rasa yang enak dengan harga yang murah. Apabila pemanfaatan olahan kedelai atau tahu meningkat dan permintaan pasar juga meningkat, maka akan berdampak pula pada peningkatan hasil produk tahu di dunia industri. Peningkatan produk ini dapat meningkatkan unit-unit produksi tahu sehingga berdampak pada daya serap tenaga kerja dan berdampak luas kepada semua faktor. Berkembangnya aneka industri berbahan baku kedelai di Indonesia, telah mendorong meningkatnya permintaan komoditas kedelai dari tahun ke tahun. Sedangkan pasokan komoditas kedelai lokal masih belum memenuhi tingginya permintaan. Kebutuhan kedelai dalam negeri sebahagian besar masih di pasok oleh produk impor. Masih tingginya ketergantungan Indonesia terhadap produk kedelai impor menyebabkan harga kedelai masih terbilang tinggi dan seringkali mengalami fluktuasi disebabkan terpengaruh oleh harga kedelai di pasar. Hal ini menjadi permasalahan yang seringkali dihadapi oleh para pelaku usaha di sektor industri berbasis kedelai. Meskipun bahan baku masih menjadi faktor kendala bagi industri berbasis kedelai, hal ini tidak membuat surut para pelaku usaha di sektor ini yang pada umumnya industri skala rumah tangga, kecil, dan menengah. Seiring dengan meningkatnya jumlah penduduk Indonesia, maka dapat diprediksikan permintaan akan produk olahan 
berbahan dasar kedelai akan terus meningkat. Oleh karena itu, industri berbasis kedelai memiliki potensi yang sangat besar untuk dikembangkan. Dalam praktiknya industri pembuatan tahu dapat mengembangkan usahanya menjadi lebih baik dengan mengembangkan strategi untuk mengatasi ancaman eskternal dengan memperebut peluang yang ada. Tujuan utama perencanaan strategis perusahaan adalah agar perusahaan dapat melihat secara objektif kondisi-kondisi internal dan eksternal, sehingga perusahaan dapat mengantisipasi perubahan lingkungan eksternal dan memperoleh keunggulan bersaing. Meningkatnya persaingan yang terjadi akibat banyaknya bermunculan usaha tahu mengakibatkan pengaruh perubahan strategi. Sehingga pelaku usaha yang bergerak di bidang ini harus dapat membuat strategi yang tepat agar mampu bertahan dan berkembang.
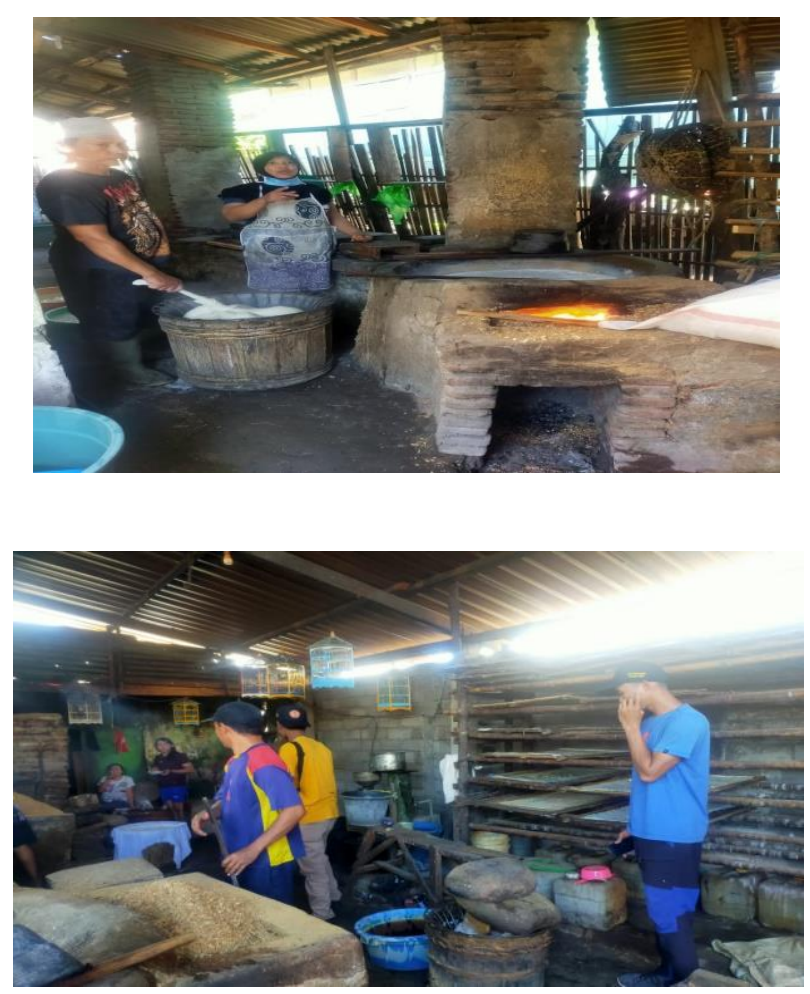

Berdasarkan analisa SWOT yang telah dilakukan maka didapatkan strategi solusi yang cocok bagi perusahaan yaitu:

1. Cost Leadership

Dimana Strategi ini dirancang karena dalam industri tahu dengan target pasar saat ini yaitu pedagang pasar tradisional, hal yang terutama harus dipenuhi adalah harga yang murah serta kualitas terjaga. Harga tahu yang semakin murah membuat customer tertarik dan membelinya. Oleh karena itu, Tahu bapak A dapat menerapkan strategi cost leadership dengan meningkatkan skala produksi dan peningkatan efisiensi agar harga pokok penjualan dapat lebih rendah sehingga perusahaan dapat menjual tahu dengan harga lebih murah.

2. Differentiation

Dimana dalam menarget pasarnya yang ada sekarang perusahaan harus menggunakan cost leadership. Namun untuk mengatasi ketatnya persaingan yang ada, perusahaan juga perlu menarget segmen lain. Perusahaan harus membik masyarakat yang mulai menerapkan gaya hidup sehat yang terutama berasal dari kalangan menengah atas yang memiliki daya beli cukup tinggi. Perusahaan dapat menjual produknya ke masyarakat menengah keatas dengan membuat jenis produk

Ekonomi, Sosial, dan Budaya | 1368 
yang berbeda yaitu dengan kemasan yang diberi merek dan berbagai informasi nilai gizi yang terkandung pada tahu. Tentunya produk ini dipasarkan melalui saluran distribusi yang berbeda yaitu pasar retail modern, seperti supermarket dan hypermarket. Pemilihan saluran distribusi tersebut karena ada kecenderungan kalangan menengah keatas yang peduli kesehatan telah beralih dari pasar tradisional ke pasar modern dan rela membayar lebih untuk produk yang sama hanya dengan kemasan yang lebih menarik. Kemasan dan harga yang berbeda akan menimbulkan persepsi yang berbeda walaupun sebenarnya tidak banyak perbedaan dari isi produk. Dengan adanya nilai tambah tersebut dan target pasar yang berdaya beli lebih tinggi tentunya harga jual produk juga akan lebih mahal dan margin laba yang lebih besar.

3. Backward Integration

Dimana Strategi ini dirancang agar UD.Pabrik Tahu Saudara bapak Amin tidak perlu lagi membeli bahan baku dari pemasok. Akan lebih baik jika UD.Pabrik Tahu membuat usaha pertanian khusus kacang kedelai, dimana nantinya kacang kedelai tersebut digunakan untuk pembuatan tahu sendiri. Dengan adanya hal tersebut,
UD.Pabrik Tahu pak Amin akan terintegrasi antara pemasok kacang kedelai dan pengolah kacang kedelai sehingga harganya bisa lebih murah. Strategi ini juga sangat berguna untuk mengatasi masalah tidak stabilnya harga bahan baku karena jumlah pasokan di pasar yang tidak stabil. Di sisi lain, meski strategi ini memiliki risiko gagal panen karena kurangnya pengalaman. Untuk meminimalkan risiko ini, perusahaan disarankan hanya membeli tanah dan menyerahkan pengelolaan pertanian tersebut pada petani kacang kedelai yang telah berpengalaman meski tetap ada risiko gagal panen karena faktor alam yang diluar kendali manusia. Tetapi secara keseluruhan, keuntungan dan risiko dari strategi ini lebih menguntungkan daripada menanggung risiko kenaikan harga yang sangat fatal bagi produsen tahu.

\section{KESIMPULAN}

Strategi-strategi tersebut harus didukung dengan kebijakan untuk merealisasikannya. Kebijakan yang dapat mendukung strategi tersebut adalah menambah modal dengan memaksimalkan perhatian pemerintah setempat dengan memaksimalkan program pemberdayaan selaras, disamping mereka meningkatkan modal sendiri dan menggunakan pinjaman bank. 
Kebijakan tersebut digunakan untuk mendukung kebijakan menambah kapasitas melalui peralatan dan jumlah tenaga kerja untuk seluruh fungsi bisnis perusahaan, serta untuk pengembangan produk baru yang menarget segmen menengah ke atas berikut pemasarannya, dan menjamin kestabilan bahan baku dengan membuat pertanian kedelai sendiri.

\section{UCAPAN TERIMA KASIH}

Dalam pelaksanaan Pemgambdian kepada masyarakat ini, saya mengucapkan terima kasih kepada semua pihak, antara lain, Lembaga Sekolah Tinggi Ilmu Hukum Muhammadiyah Bima, Pemerintah Desa Nowa Kecamatan Woja Kabupaten Dompu, Masyarakat dan pihak-pihak lain yang berkontribusi dalam penyusunan pengabdian kepada masyarakat ini.

\section{REFERENSI}

Dewi, I. A. (2019). Analisis Strategi Pengembangan Usaha Tahu Rumah Tangga di Kelurahan Dadimulyo, Kecamatan Kisaran Barat, Kabupaten Asahan.

Dongoran, S. R. (2019). Manajemen Produksi Tahu Tempe dalam Meningkatkan Pendapatan Usaha Ditinjau Menurut Ekonomi Syariah (Doctoral dissertation, UNIVERSITAS ISLAM NEGERI SULTAN SYARIF KASIM RIAU).

Tandian, F. R. (2013). Pengelolaan dan Pengembangan Usaha Produksi Tahu pada Perusahaan Keluarga Ud. pabrik Tahu Saudara di Surabaya. Agora, 1(2), 911-916. 